Tropical Journal of Pharmaceutical Research January 2020; 19 (1): 11-15

ISSN: $1596-5996$ (print); 1596-9827 (electronic)

(C) Pharmacotherapy Group, Faculty of Pharmacy, University of Benin, Benin City, 300001 Nigeria.

\title{
Potentiation of raloxifene cytotoxicity against MCF-7 breast cancer cell lines via transdermal delivery and loading on self-emulsifying nanoemulsions
}

\author{
Hibah M Aldawsari ${ }^{1}$, Aya A Negm ${ }^{2}$ \\ Department of Pharmaceutics, King Abdulaziz University, Jeddah, Saudi Arabia \\ *For correspondence: Email: dr.hibah2018@hotmail.com; Tel: +966-543627789
}

Sent for review: 15 April 2019

Revised accepted: 22 December 2019

\begin{abstract}
Purpose: To enhance raloxifene $(R L X)$ delivery and cytotoxicity against breast cancer (MCF-7) cell lines.

Methods: This was a solubility study of RLX in different oils, surfactants, and co-surfactants. Twelve formulae were tested to reach the smallest globular size, and hydroxypropyl methylcellulose, (HPMC), and Carbopol 947 polymers were tested for formation of transdermal films. The formula with the lowest size was compared with raw RLX in diffusion studies using a Franz diffusion cell. Finally, a cytotoxicity study against MCF-7 breast cancer cell lines was conducted

Results: The maximum solubility of RLX was in Tween 80, peppermint oil, and PEG 200; therefore, these were the main components of the 12 formulations. The release of $R L X$ loaded on the selfnanoemulsion drug delivery system (SNEDDS) was increased 3-fold compared with raw $R L X$. Cytotoxicity results revealed that RLX SNEDDs decreased MCF-7 cell survival by approximately $40 \%$, compared with raw $R L X$ (control), which augmented the $R L X$ suppression of breast cancer cell lines.

Conclusion: Improvement in RLX cytotoxicity is a novel strategy to suppress breast cancer.
\end{abstract}

Keywords: Raloxifene, Osteoporosis, Bioavailability, Nanoemulsion, Nanoparticles

\begin{abstract}
This is an Open Access article that uses a fund-ing model which does not charge readers or their institutions for access and distributed under the terms of the Creative Commons Attribution License (http://creativecommons.org/licenses/by/4.0) and the Budapest Open Access Initiative (http://www.budapestopenaccessinitiative.org/read), which permit unrestricted use, distribution, and reproduction in any medium, provided the original work is properly credited.

Tropical Journal of Pharmaceutical Research is indexed by Science Citation Index (SciSearch), Scopus, International Pharmaceutical Abstract, Chemical Abstracts, Embase, Index Copernicus, EBSCO, African Index Medicus, JournalSeek, Journal Citation Reports/Science Edition, Directory of Open Access Journals (DOAJ), African Journal Online, Bioline International, Open-J-Gate and Pharmacy Abstracts
\end{abstract}

\section{INTRODUCTION}

Raloxifene $(R L X)$ is used to treat osteoporotic postmenopausal women and may also lower the chances of acquiring certain types of breast cancers (i.e., invasive breast cancer) [1]. RLX is not an oestrogen hormone, but it acts like oestrogen in some parts of the body. During menopause, oestrogen levels in the blood decrease, affecting bone cells and tissues. RLX acts like an oestrogen blocker [2]. Further, RLX does not relieve menopausal symptoms such as hot flashes, as it belongs to a class of drugs known as selective oestrogen receptor modulators (SERMs). The main problem is to improve its low bioavailability $(2 \%)$ resulting from excessive hepatic metabolism [3].

Nanoemulsions consist of nanosized droplets with a diameter of $<300 \mathrm{~nm}$, typically $20-200$ $\mathrm{nm}$. The thermodynamically non-balance of these transparent, heterogeneous dispersions of 
two non-mixtures fluids are found in [4]. Thanks to the long, almost several months, kinetic destabilization, they are kinetically stable. Nearly four decades ago, their bioavailability was investigated. Nanoemulsions are also referred to as thermodynamic solidity due to the presence of fine beads, which resist sedimentation, flocculation, and mixing due to Brownian motion $[5,6]$. These nanovehicles provide the benefits of high interfacial zones, straightforwardness of preparation, low thickness, and long-lasting colloidal states, both for hydrophilic and hydrophobic medications. Thus, they provide increased dependability, more prominent transmucosal and transdermal medication conveyance, and, consequently, enhanced bioavailability $[7,8]$.

In addition, nanoemulsions convey noteworthy wetting, spreading, and entrance capacities and can be scaled up because of their simplicity of fabrication. Nanoemulsions are also strong, accounting for their effectiveness, which additionally enhances their usefulness. The bioavailability of the emulsions are enhanced incrementally when the bead sizes approach 100,90 , and $30 \mathrm{~nm}$. The purpose of this study was to improve $R L X$ bioavailability through the use of self-nanoemulsion drug delivery systems (SNEDDS) stacked in a transdermal location to maintain a strategic distance from digestive processes [9].

\section{EXPERIMENTAL}

\section{Materials}

RLX powder was a gift from EIPICO Pharmaceuticals (Cairo, Egypt); olive oil, castor oil, Tween 20 polysorbates, polyethylene glycol 200, glycerin, dill oil, ethyl alcohol, Tween 80, and sesame oil were purchased from SigmaAldrich (Dusseldorf, Germany).

\section{Solubility study}

The solubilities of RLX in various oils (olive, sesame, dill, castor, and peppermint), surfactants (Tween 80 and Span 80), and co-surfactants (PEG 200 , ethyl alcohol, and glycerine) were determined by the addition of excess amounts of the drug to screw-capped glass vials containing 1 $\mathrm{mL}$ of each of the solutions. The mixtures were placed in a thermostatically controlled shaking water bath at $37^{\circ} \mathrm{C}$ for $24 \mathrm{~h}$. The vial contents were then examined for clarity; if it was clear, more drug was added. Then, the mixtures were centrifuged at $15,000 \mathrm{rpm}$ for $1 \mathrm{~h}$. The supernatant was diluted with methanol, and the concentration was determined by ultraviolet (UV) spectrophotometry at a wavelength of $289 \mathrm{~nm}$.

\section{Preparation of nanoemulsion}

Based on the above-mentioned solubility studies, the selected oil (peppermint oil), surfactant (Tween 80), and co-surfactant (PEG 200) were chosen for preparation of nanoemulsions. Twelve formulae were prepared using varying concentrations of oil, surfactant, and cosurfactant with $30 \mathrm{mg}$ of the drug, as shown in Table 1. For any mixture, the total weight of the three components was always maintained at 2 gm.

Table 1: Composition of nano emulsion formulations

\begin{tabular}{lcccc} 
Batch & $\begin{array}{c}\text { Peppermint } \\
\text { oil } \\
\text { (mg) }\end{array}$ & $\begin{array}{c}\text { Tween } \\
\mathbf{8 0} \\
(\mathbf{m g})\end{array}$ & PEG200 & $\begin{array}{c}\text { Globular } \\
\text { size }\end{array}$ \\
\hline F1 & 0.35 & 0.5 & 0.15 & (nm) \\
F2 & 0.35 & 0.55 & 0.1 & 234 \\
F3 & 0.3 & 0.475 & 0.22 & 321 \\
F4 & 0.3 & 0.55 & 0.15 & 543 \\
F5 & 0.271 & 0.501 & 0.2 & 298 \\
F6 & 0.25 & 0.55 & 0.2 & 651 \\
F7 & 0.25 & 0.475 & 0.275 & 942 \\
F8 & 0.2 & 0.55 & 0.25 & 267 \\
F9 & 0.4 & 0.425 & 0.375 & 763 \\
F10 & 0.15 & 0.475 & 0.375 & 176 \\
F11 & 0.15 & 0.375 & 0.475 & 321 \\
F12 & 0.1 & 0.35 & 0.55 & 421
\end{tabular}

\section{Globular size analysis}

A specific volume of each formula $(100 \mu \mathrm{L})$ was poured into $50 \mathrm{~mL}$ of distilled water to allow SNEDDS to form emulsions and then directly subjected to a Microcrack Nanosizer (Microtrac, Montgomeryville, PA, USA) to measure globular size and zeta potential.

\section{Globular morphology}

The globular morphology of the selected formula was studied by transmission electron microscopy (TEM) to determine the globular size and morphology. TEM analysis (TEM TECNAI $200 \mathrm{Kv}$ TEM Fei; Electron Optics, Tokyo, Japan) of the RLX SNEDDS was performed for morphological characterization and visualization of emulsion droplets. A drop of sample obtained after dilution was placed on copper grids, stained with $1 \%$ phosphotungstic acid for $30 \mathrm{~s}$, and finally analyzed by TEM to visualize the droplet morphology.

\section{Transdermal patch formulation}

The selected formula of RLX SNEDDs was poured into a polymeric solution of $1 \%$ of HPMC, 
HPC, and chitosan for the preparation of transdermal patches. All films used $1 \mathrm{~g}$ of each polymer in $100 \mathrm{~mL}$ tap water with $30 \mathrm{mg} \mathrm{RLX}$ powder as the control. Polymeric solutions were poured into petri dishes and covered with aluminum foil and then transferred to a $45^{\circ} \mathrm{C}$ oven until complete evaporation of the solvent was achieved. All films were characterized for folding properties, appearance, and film elongation, as shown in Figure 2 (RLX SNEDDS TEM morphology).

\section{Preparation of RLX SNEDDs transdermal patch}

The prepared polymeric solutions were stored in an oven at $45^{\circ} \mathrm{C}$ for almost three days. The four patches were not completely dry and had a bright yellow color. Before cutting the patches, the drug contents of a $1.5 \mathrm{~cm}$ two piece from each sample was calculated.

\section{In vitro release studies}

The prepared patches were tested for diffusion of drug using automated Franz diffusion cell apparatus (Microette plus, USA) with a diffusion area of $2.85 \mathrm{~cm}$ and $7 \mathrm{ml}$ volume receptor chamber. Patches prepared with $R L X$, and the Formula 10 was used. In the receptor chamber, a buffer with the $\mathrm{pH} 7.2$ was used as a medium at $32.5{ }^{\circ} \mathrm{C} \pm 2.0$, and the rate of stirring was 400 rpm. The auto sampler is programmed to take samples of the buffer solution at preselected times $(0: 30,1,2,4,6,8,12 \mathrm{~h})$ with equal amounts to the receptor chamber. HPMC was chosen as a transdermal patch matrix.

\section{Evaluation of RLX SNEDDs cytotoxicity against MCF-7 $\mathrm{c}$ ells}

MCF-7 breast cancer cells were gifted from Dr Serag El-bahiry's, Cell Culture Lab, Faculty of Science, King Khalid University, Abha, KSA. The cells were grown in complete growth media composed of $5 \%$ fetal bovine serum (FBS), 2 $\mathrm{mM}$ L-glutamine, $100 \mu \mathrm{g} / \mathrm{mL}$ streptomycin, 100 $\mathrm{U} / \mathrm{ml}$ penicillin, and $2.2 \mathrm{~g} / \mathrm{NaHCO}_{3}$. Cells were maintained at $37{ }^{\circ} \mathrm{C}$ in a humidified atmosphere of $5 \% \mathrm{CO}_{2}$. MCF-7 breast cancer cells were seeded in 96 well plates, incubated for $24 \mathrm{~h}$ at 37 ${ }^{\circ} \mathrm{C}$ in $5 \% \mathrm{CO} 2$, and then treated with $\mathrm{RLX}$ or RLX SNEDDs. DMSO (0.1\%) served as the vehicle control. The cells were incubated for $72 \mathrm{~h}$ and fixed using a trichloroacetic acid (TCA) 10\% solution. Cell number was determined using the sulforhodamine B (SRB) assay. The concentration required to decrease cell number by $50 \%\left(\mathrm{IC}_{50}\right)$ was determined by nonlinear regression using Prism software. For the time- course analysis, cells were treated with $R L X$ or RLX SNEDDs $(0.01-100 \mu \mathrm{g} / \mathrm{mL})$. Three independent experiments were performed in triplicate.

\section{RESULTS}

We experimented with the oils to see which one has the highest solubility of RLX and found that the peppermint oil has the highest RLX solubility with a concentration of $1.69 \mathrm{mg} / \mathrm{mL}$. The highest solubility was found with the surfactants and cosurfactants; further, Tween 80 had the highest of the surfactants with a concentration of 3.703 $\mathrm{mg} / \mathrm{mL}$, and PEG 200 had the highest of the cosurfactants with a concentration of $4.917 \mathrm{mg} / \mathrm{mL}$, as shown in Figure 1.

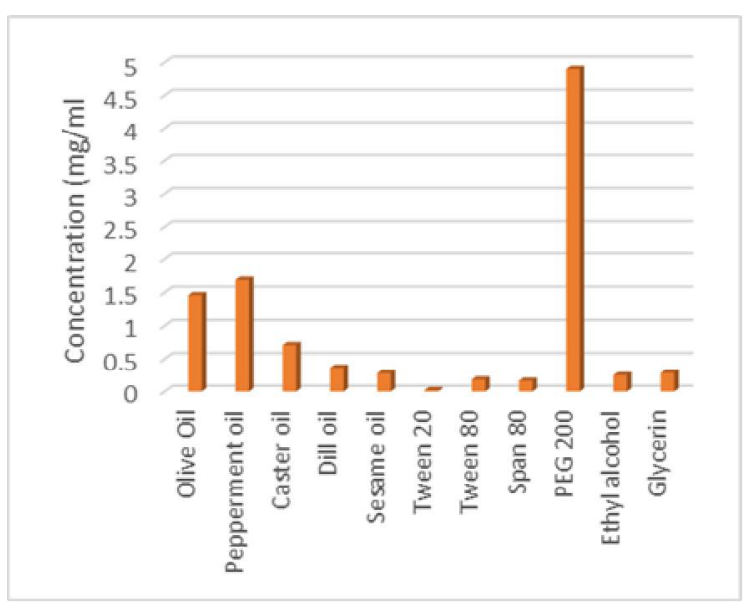

Figure 1: $R L X$ solubility study in different oils, surfactant, and co-surfactant

With regard to RLX SNEDDS morphology, TEM images show circular globules with size less than $1 \mu \mathrm{m}$; this spherical globule facilitates skin penetration and homogenize rate of diffusion, as shown in Figure 2.

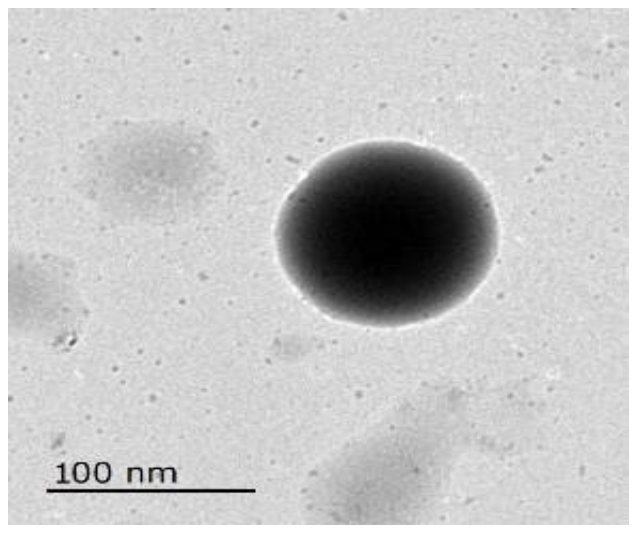

Figure 2. RLX SNEDDS TEM image

\section{In vitro drug release}


The prepared patches were tested for diffusion of the drug using an automated Franz diffusion cell apparatus (Microette ${ }^{\mathrm{TM}}$ Plus, USA) with a diffusion area of $2.85 \mathrm{~nm}$ and a $7 \mathrm{~mL}$ volume receptor chamber. The patches prepared with $\mathrm{RLX}$ and Formula 10 were used. In the receptor chamber, a buffer ( $\mathrm{pH} 7.2$ ) was used as a medium at $32.5 \pm 2.0^{\circ} \mathrm{C}$, and the rate of stirring was $400 \mathrm{rpm}$. The autosampler was programmed to take samples of the buffer solution at preselected times (0 and $30 \mathrm{~min}$, and 1, 2, 4, 6, 8 , and $12 \mathrm{~h}$ ) with equal amounts to the receptor chamber. HPMC was chosen as a transdermal patch matrix.

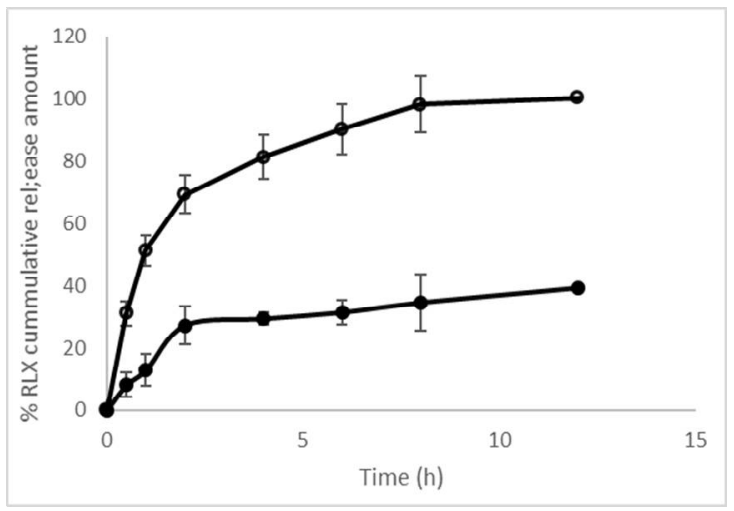

Figure 3: \% of RLX cumulative released after 12 h.,(O) refer to $\mathrm{RLX}$ transdermal patch while $(\mathrm{O})$ refers to Raw -RLX

To provide the potency of RLX SNEDDS raw RLX in the MCF-7 breast cancer cell lines, IC50 curves were initially produced. Both raw RLX and RLX SNEDDS demonstrated a consistent cytotoxicity across the cell lines, but $R L X$ SNEDDS was more potent than raw RLX. Specifically, IC50 values for RLX SNEDDS was $2.77 \pm 0.38 \mu \mathrm{M}$, while the raw RLX was $1.98 \pm$ $0.17 \mu \mathrm{M}$, as shown in Figure 4 .

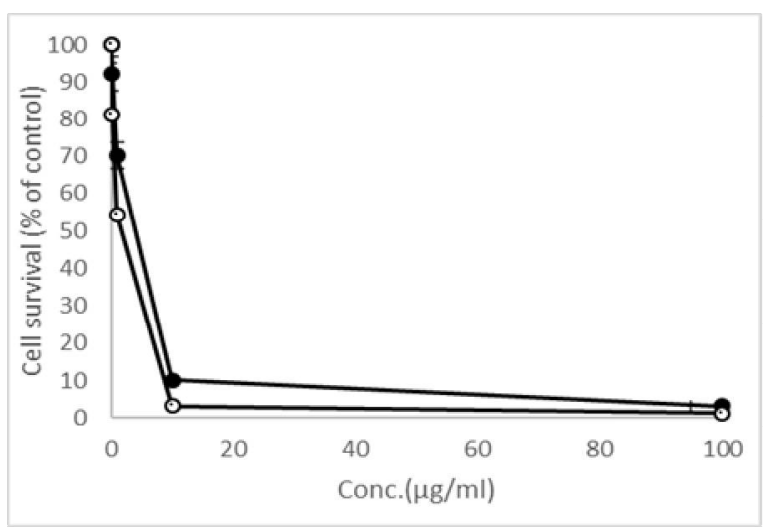

Figure 5: $\quad \mathrm{IC}_{50}(\%)$ of Raw $\mathrm{RLX}$ and $\mathrm{RLX}$ SNEDDS. (0) denote RLX SNEDDS while $(O)=$ Raw -RLX
Nanoemulsions are structures that are thermodynamically stable and grow when a particular solution quantity is poured into liquid. When the peppermint oil concentration decreased from Tween 80 to PEG 200[4], a higher region of nanoemulsion was found, and about $35 \%$ of dill oil was solubilized. The interfacial tension may be further reduced by increasing the interface fluidity; therefore, the oil stage may further penetrate the hydrophobic area of 80 monomer. The inclusion of PEG 200 as a co-factant minimized the interface end tension and rendered the interface film versatile enough to show multiple curvatures needed to form nanoemulsion under a range of circumstances. The nanoemulsion region decreased when the amount of PEG200 was raised in contrast to Tween 80 , leading to the creation of a smaller quantity of micelles [10].

The improved cell cytotoxicity and penetration of SNEDD RLX can be used to improve raw RLX dose effectiveness against cancer cells MCF-7, which could reduce RLX adverse events [11-13]. SNEDDs are taken by human cells through a number of concurrent pathways. SNEEDs increase $R L X$ inclusion and enhance mobile RLX absorption by attracting a cell membrane negatively charged and activating a receptor-free cascade, contributing to the incorporation of RLX into the cellular cytoplasm. The interaction between SNEDDs and the cell membrane includes the lure of proteoglycans and surfactants. Therefore, SNEDDs activate intracellular signalling cascades, which enhance the organic cycle of absorption.

SNEDDs can penetrate cells using distinctive endocytic pathways such as pinocytosis along with macropinocytosis, clathrin-mediated endocytosis, caveolae or Q7 lipid-raft-mediated endocytosis, and clathrin-or caveolae-impartial endocytosis. Endocytic uptake pathways rely on peptide characteristics, load characteristics of SNEDD, and specific cell characteristics. Transport of RLX may be controlled with the aid of the extracellular carrier system's metabolism, which involves peptide uptake, and intracellular degradation in endocytic vesicles. Endosomal escape could help to prevent degradation of RLX in lysosomes and thus aid the delivery of RLX to its biological target [14-16].

\section{CONCLUSION}

A new dosage form of $R L X$ as a transdermal patch to overcome extensive hepatic first-pass metabolism of oral dosage using SNEDDs was established. After conducting in vitro release studies of films, the results showed that RLX 
transdermal patches demonstrated a $>3$-fold release of $R L X$ compared with raw $R L X$, which suggested a significant enhancement in RLX bioavailability to improve cytotoxicity. This novel method could potentially be used for suppressing breast cancer cells.

\section{DECLARATIONS}

\section{Conflict of interest}

No conflict of interest is associated with this work.

\section{Contribution of authors}

We declare that this work was done by the authors named in this article and all liabilities pertaining to claims relating to the content of this article will be borne by the authors.

\section{Open Access}

This is an Open Access article that uses a funding model which does not charge readers or their institutions for access and distributed under the terms of the Creative Commons Attribution License (http://creativecommons.org/licenses/by/ 4.0) and the Budapest Open Access Initiative (http://www.budapestopenaccessinitiative.org/rea d), which permit unrestricted use, distribution, and reproduction in any medium, provided the original work is properly credited.

\section{REFERENCES}

1. Kulkarni J, Gavrilidis E, Gwini SM, Worsley R, Grigg J, Warren $A$, et al. Effect of adjunctive raloxifene therapy on severity of refractory schizophrenia in women: $A$ randomized clinical trial. JAMA Psychiatry. 2016; 73: 947-954. doi:10.1001/jamapsychiatry.2016.1383

2. Vachon CM, Schaid DJ, Ingle JN, Wickerham DL, Kubo $M$, Mushiroda $T$, et al. A polygenic risk score for breast cancer in women receiving tamoxifen or raloxifene on NSABP P-1 and P-2. Breast Cancer Res Treat. 2015; 149: 517-523. doi:10.1007/s10549-014-3175-4

3. de Boer J, Prikken M, Lei WU, Begemann M, Sommer I. The effect of raloxifene augmentation in men and women with a schizophrenia spectrum disorder: a systematic review and meta-analysis. npj Schizophr. 2018; 4: 1. doi:10.1038/s41537-017-0043-3

4. Wang L, Dong J, Chen J, Eastoe J, Li X. Design and optimization of a new self-nanoemulsifying drug delivery system. J Colloid Interface Sci. Elsevier Inc.2009; 330 : 443-448. doi:10.1016/j.jcis.2008.10.077
5. Glimelius B, Hoffman $K$, Sjödén $P O$, Jacobsson $G$, Sellström $H$, Enander $L K$, et al. Chemotherapy improves survival and quality of life in advanced pancreatic and biliary cancer. Ann Oncol. 1996; 7: 593-600. doi:10.1016/0959-8049(95)95809-K

6. Skehan P, Storeng R, Scudiero D, Monks A, McMahon J, Vistica $D$, et al. New colorimetric cytotoxicity assay for anticancer-drug screening. J Natl Cancer Inst. 1990; 82: 1107-12. Available: http://www.ncbi.nlm.nih.gov/pubme d/2359136

7. Czene K, Lichtenstein P, Hemminki K. Environmental and heritable causes of cancer among 9.6 million individuals in the Swedish Family-Cancer Database. Int J Cancer. 2002; 99: 260-266. doi:10.1002/ijc.10332

8. Browning DRL, Martin RM. Statins and risk of cancer: $A$ systematic review and metaanalysis. Int J Cancer. 2007; 120: 833-843. doi:10.1002/ijc.22366

9. Tanuma S, Powell CJ, Penn DR. Calculations of electron inelastic mean free paths (IMFPS). IV. Evaluation of calculated IMFPs and of the predictive IMFP formula TPP???2 for electron energies between 50 and 2000 eV. Surf Interface Anal. 1993; 20: 77-89. doi:10.1002/sia.740200112

10. Yokoyama M. Polymeric micelles as a new drug carrier system and their required considerations for clinical trials. 2010; 145-158.

11. Kim CW, Yun YP, Lee HJ, Hwang YS, Kwon IK, Lee SC. In situ fabrication of alendronate-loaded calcium phosphate microspheres: Controlled release for inhibition of osteoclastogenesis. J Control Release. Elsevier B.V.; 2010; 147: 45-53. doi:10.1016/j.jconrel. 2010.06.016

12. Tipton DA, Seshul BA, Dabbous MK. Effect of bisphosphonates on human gingival fibroblast production of mediators of osteoclastogenesis: RANKL, osteoprotegerin and interleukin-6. J Periodontal Res. 2011; 46: 39-47. doi:10.1111/j.1600-0765.2010.01306.x

13. Song L, Xie XB, Peng LK, Yu SJ, Peng YT. Mechanism and treatment strategy of osteoporosis after transplantation. Int J Endocrinol. 2015; 2015. doi:10.1155/2015/280164

14. Ferreira $D$ dos $S$, Boratto $F A$, Cardoso VN, Serakides $R$, Fernandes SO, Ferreira LAM, et al. Alendronate-coated long-circulating liposomes containing 99mtechnetiumceftizoxime used to identify osteomyelitis. Int $\mathrm{J}$ Nanomedicine. 2015; 10: 2441-2450. doi:10.2147/IJN.S76168

15. Chen G, Wang C, Wang J, Yin S, Gao H, Xiang L, et al. Antiosteoporotic effect of icariin in ovariectomized rats is mediated via the Wnt/ $\beta$-catenin pathway. Exp Ther Med. 2016; 12: 279-287. doi:10.3892/etm.2016.3333

16. Kim SE, Yun YP, Lee DW, Kang EY, Jeong WJ, Lee B, et al. Alendronate-eluting biphasic calcium phosphate (BCP) scaffolds stimulate osteogenic differentiation. Biomed Res Int. 2015; 2015. doi:10.1155/2015/320713. 